\title{
Hexane fraction of Pluchea indica root extract inhibits proliferation and induces autophagy in human glioblastoma cells
}

\author{
CHUNG-LUNG CHO ${ }^{1}$, YA-ZHE LEE ${ }^{1}$, CHAO-NENG TSENG ${ }^{1,5}$, JOSHUA CHO $^{2}$, YUAN-BIN CHENG ${ }^{3}$, \\ KUO-WEI WANG ${ }^{4}$, HAN-JUNG $\mathrm{CHEN}^{4}$, SHEAN-JAW CHIOU ${ }^{5}$, CHIA-HUA CHOU ${ }^{6}$ and YI-REN HONG ${ }^{1,5,6}$ \\ ${ }^{1}$ Department of Biological Sciences, National Sun Yat-sen University, Kaohsiung 80424, Taiwan, R.O.C.; ${ }^{2}$ University of \\ Pennsylvania School of Dental Medicine, Philadelphia, PA 19104, USA; ${ }^{3}$ Graduate Institute of \\ Natural Products, School of Pharmacy, Kaohsiung Medical University, Kaohsiung 80708; \\ ${ }^{4}$ Department of Neurosurgery, E-Da Hospital, I-Shou University, Kaohsiung 84001; \\ ${ }^{5}$ Department of Biochemistry and ${ }^{6}$ Institute of Medicine, College of Medicine, \\ Kaohsiung Medical University, Kaohsiung 80708, Taiwan, R.O.C.
}

Received July 27, 2017; Accepted September 7, 2017

DOI: $10.3892 /$ br.2017.979

\begin{abstract}
Pluchea indica (L.) Less. is a perennial plant known for its versatile uses in traditional medicine. Previous findings have shown that the extracts of Pluchea indica possess significant anti-inflammatory, anti-ulcer and anti-tuberculosis activity. The aim of this study was to demonstrate the anticancer activity of the hexane fraction of $P$.indica root extract (H-PIRE) in human glioblastoma cells using flow cytometric and western blot analysis. The results shoewd that, H-PIRE suppressed the growth of glioblastoma cells in a dose-dependent manner. H-PIRE treatment markedly decreased the population of cells in $\mathrm{S}$ and $\mathrm{G} 2 / \mathrm{M}$ phases. The significant upregulation of acidic vesicular organelle (AVO) was detected during H-PIRE treatment. The expression levels of microtubule-associated light chain 3-II (LC3-II) protein, phosphorylated JNK and phosphorylated p38 were significantly increased, confirming the occurrence of autophagy during the process. Finally, the combination treatment of H-PIRE and LY294002, a pan PI3K inhibitor, further decreased cell viability, suggesting an additive anticancer effect. Taken together, our results suggest that H-PIRE suppresses the proliferation of glioblastoma cells by inducing cell cycle arrest and autophagy.
\end{abstract}

Correspondence to: Dr Chung-Lung Cho, Department of Biological Sciences, National Sun Yat-sen University, 70 Lienhai Road, Kaohsiung 80424, Taiwan, R.O.C.

E-mail: clcho@mail.nsysu.edu.tw

Dr Yi-Ren Hong, Department of Biochemistry, College of Medicine, Kaohsiung Medical University, 100 Shih-Chung 1st Road, Kaohsiung 80708, Taiwan, R.O.C.

E-mail: m835016@cc.kmu.edu.tw

Key words: anticancer, acidic vesicular organelle, LC3-II, JNK, p38

\section{Introduction}

Glioblastoma multiforme (GBM) is among the most common malignant cancers of the brain (1). Although the main cause of this disease remains unknown, possible risk factors include genetic disorder (2), viral infection (3), alcohol consumption (4) and ionizing radiation exposure (5). Standard treatments for GBM include surgicael resection, chemotherapy (e.g., temozolomide therapy) and radiotherapy $(6,7)$. As GBM spreads rapidly and has a high potential for relapse even the most aggressive treatment rarely achieves survival $>3$-years and the median survival time is approximately 1-year $(7,8)$. Complementary and alternative therapies commonly used in GBM patients include vitamin and nutrient supplements as well as herbal extracts (9). Some clinical evidence shows that treatment with herbal extracts can reduce mortality in GBM patients (10).

Pluchea indica (L.) Less. (Asteraceae) is a perennial shrub with medicinal properties that are widely recognized in many Asian countries (11). P. indica is traditionally used to heal minor wounds because it has astringent, antipyretic and antiinflammatory activities $(11,12)$. The leaves of $P$. indica contain $\alpha$-glucosidase inhibitors that could help treat diabetes mellitus by suppressing carbohydrate digestion (13). Methanol extracts of the $P$. indica root are known to neutralize snake venoms (14) and contain anti-amoebic activities (15). The methanol fraction of $P$. indica root and leaf extracts has revealed potent anti-ulcer (16) and anti-tuberculosis effects (17). The aqueous extract of $P$. indica has antiviral activity against human immunodeficiency virus type 1 (18). Quinic acid esters from the leaves of $P$. indica showed inhibitory activities towards collagenase, MMP-2 and -9 (19). In vitro studies also revealed that crude aqueous extracts and ethanol extracts of $P$. indica root effectively suppress human malignant glioma cancer cells and human cervical cancer cells $(20,21)$.

Therefore, the aim of this study was to investigate the underlying mechanisms of the anticancer effects of the hexane fraction of $P$. indica root extract (H-PIRE) in human U87 GBM cells and primary GBM cells. 


\section{Materials and methods}

Plant material and extraction. The $P$. indica plants used in experiments in this study were collected and verified as described in a previous study (20). The roots of $P$. indica were prepared as a dried powder and deposited at the National Sun Yat-sen University (Kaohsiung, Taiwan, R.O.C.) and the H-PIRE was extracted using the method described by Kao et al (21). Briefly, the $P$. indica extract was prepared by immersing the root powder in $95 \%$ (v/v) ethanol at room temperature overnight, filtering with $0.45 \mu \mathrm{m}$ filters, then partitioning the water and ethyl acetate (v/v, 1:1). The ethyl acetate fraction was further partitioned with a 1:1 (v/v) mixture of $75 \%$ ethanol and hexane. The hexane layer was collected and concentrated to obtain powdered H-PIRE. The powdered H-PIRE was then dissolved in dimethyl sulfoxide (DMSO) to desired concentrations in subsequent experiments.

Preliminary phytochemical analysis. Total phenolic compound content was determined with Folin-Ciocalteu reagent and presented as gallic acid equivalents in $\mathrm{mg} / \mathrm{g}$ of extract. Total flavonoid content was determined by aluminum chloride colorimetric method and expressed as catechin equivalents in $\mathrm{mg} / \mathrm{g}$ of extract (22). Condensed tannin (proanthocyanidin) content was analyzed by vanillin assay method as described by Butler et al (23) and presented as catechin equivalents in $\mathrm{mg} / \mathrm{g}$ of extract. All assays were performed in triplicate.

Cell culture. Primary GBM cells were enzymatically dissociated from fresh glioblastoma samples as described by Pavon et al (24), according to a protocol approved by the Kaohsiung Medical University Institutional Review Board (Kaohsiung, Taiwan, R.O.C.). The U87 and primary GBM cell lines were cultured in Dulbecco's modified Eagle's medium with $10 \%$ fetal bovine serum (all from HyClone; GE Healthcare Life Sciences, Logan, UT, USA), 200 mM l-glutamine (Invitrogen Life Technologies; Thermo Fisher Scientific, Inc., Waltham, MA, USA), $1 \%$ penicillin $(10,000 \mathrm{U} / \mathrm{ml}) /$ streptomycin $(10,000 \mathrm{U} / \mathrm{ml})$ (HyClone; GE Healthcare Life Sciences Hyclone), 1X non-essential amino acids and $1 \mathrm{mM}$ sodium pyruvate (both from Invitrogen Life Technologies; Thermo Fisher Scientific, Inc.). The cells were cultured in $5 \% \mathrm{CO}_{2}$ at $37^{\circ} \mathrm{C}$ in a humidified incubator. Institutional board approval was obtained before experimental use of primary GBM cells derived from patients.

Cell viability assays. Cell viability was determined using the WST-1 colorimetric assay method. The cells were cultured overnight in 96 -well plates $\left(2 \times 10^{3}\right.$ cells/well $)$ and treated with $0-1,000 \mu \mathrm{g} / \mathrm{ml} \mathrm{H}-\mathrm{PIRE}$ or DMSO (negative control) for 24 to $72 \mathrm{~h}$. The medium was then carefully removed and replaced with fresh medium containing the cell proliferation reagent WST-1 (Roche Diagnostics GmbH, Mannheim, Germany) and the cells were incubated for an additional $3 \mathrm{~h}$ at $37^{\circ} \mathrm{C}$. Absorbance was measured at $450 \mathrm{~nm}$ with an ELISA plate reader (Micro Quant; BioTek Instruments, Inc., Winooski, VT, USA). The $\mathrm{IC}_{50}$ values were determined as previously described (20) and presented as mean \pm standard deviation (SD) $(n=3)$.
Table I. Phytochemical content of H-PIRE.

\begin{tabular}{lc} 
Phytochemical content & Mean \pm SD \\
\hline Total phenols & $196.7 \pm 0.7 \mathrm{mg} \mathrm{GAE} / \mathrm{g} \mathrm{DW}$ \\
Total flavonoids & $113.6 \pm 0.6 \mathrm{mg} \mathrm{CE} / \mathrm{g} \mathrm{DW}$ \\
Proanthocyanidins & $28.947 \pm 0.0062 \mathrm{mg} \mathrm{CE} / \mathrm{g} \mathrm{DW}$
\end{tabular}

Mean $\pm \mathrm{SD}(\mathrm{N}=3)$; H-PIRE, hexane fraction of Pluchea indica root extract; CE, catechin equivalent; GAE, gallic acid equivalent; DW, dry weight; SD, standard deviation.

Flow cytometric analysis. Apoptosis was detected with an fluorescein isothiocyanate (FITC) Annexin V apoptosis detection kit I (BD Pharmingen, BD Biosciences, Franklin Lakes, NJ, USA). After 24 and 48 h of incubation with H-PIRE or DMSO, $1 \times 10^{5}$ cells were collected and suspended in $100 \mu \mathrm{l}$ staining buffer containing $5 \mu \mathrm{l}$ of FITC Annexin $\mathrm{V}$ and $5 \mu \mathrm{l}$ propidium iodide (PI) at room temperature in the dark. After $15 \mathrm{~min}, 400 \mu \mathrm{l} 1 \mathrm{X}$ binding buffer was added and flow cytometric analysis was performed as previously described (20).

Acridine orange staining. Cells were cultured in 60-mm dishes until $60 \%$ confluent and then treated with $300 \mu \mathrm{g} / \mathrm{ml}$ H-PIRE for $24 \mathrm{~h}$. The cells were then stained with $1 \mathrm{mg} / \mathrm{ml}$ acridine orange (AO) for $15 \mathrm{~min}$ and washed with phosphate buffer saline (PBS) to detect acidic vesicular organelles (AVOs). A fluorescence microscope (Olympus IX70; Tokyo, Japan) with an excitation filter set to $490 \mathrm{~nm}$ and a $515 \mathrm{~nm}$ long-pass filter was used for cell analysis and digital imaging.

Western blot analysis. The cells were cultured in 60-mm dishes until $60 \%$ confluent and then treated with $300 \mu \mathrm{g} / \mathrm{ml} \mathrm{H}$-PIRE for 0 to $24 \mathrm{~h}$. After incubation, the cells were washed with PBS and lysed in T-PER protein extraction reagent (Pierce). Cell lysates containing $20 \mu \mathrm{g}$ total protein were separated by sodium dodecyl sulfate-polyacrylamide gel electrophoresis and transferred to polyvinylidene difluoride membranes. Antibodies against p-p38 (1:1,000, rabbit monoclonal, Cell Signaling Technology cat. no. 4511), p-JNK (1:1,000, rabbit monoclonal, Cell Signaling Technology, cat. no. 4668), LC3B (1:1,000, rabbit monoclonal, Cell Signaling Technology cat. no. 3868) and $\beta$-actin (1:10,000, mouse monoclonal, Sigma-Aldrich,) were used for immunoblotting. The immunoblots were visualized using enhanced chemiluminescence detection reagent (Amersham; GE Healthcare, Chicago, IL, USA). A LAS-3000 CCD system was used for imaging and a Multi Gauge V2.02 both from (Fujifilm Holdings Corporation, Tokyo, Japan) was used for analysis.

Statistical analysis. Data were expressed as the mean \pm SD of three independent experiments. Statistical significance was determined by performing independent Student's t-test with SPSS 12.0 software (SPSS Inc., Chicago, IL, USA). $\mathrm{P}<0.05$ was considered to indicate a statistically significant difference. 

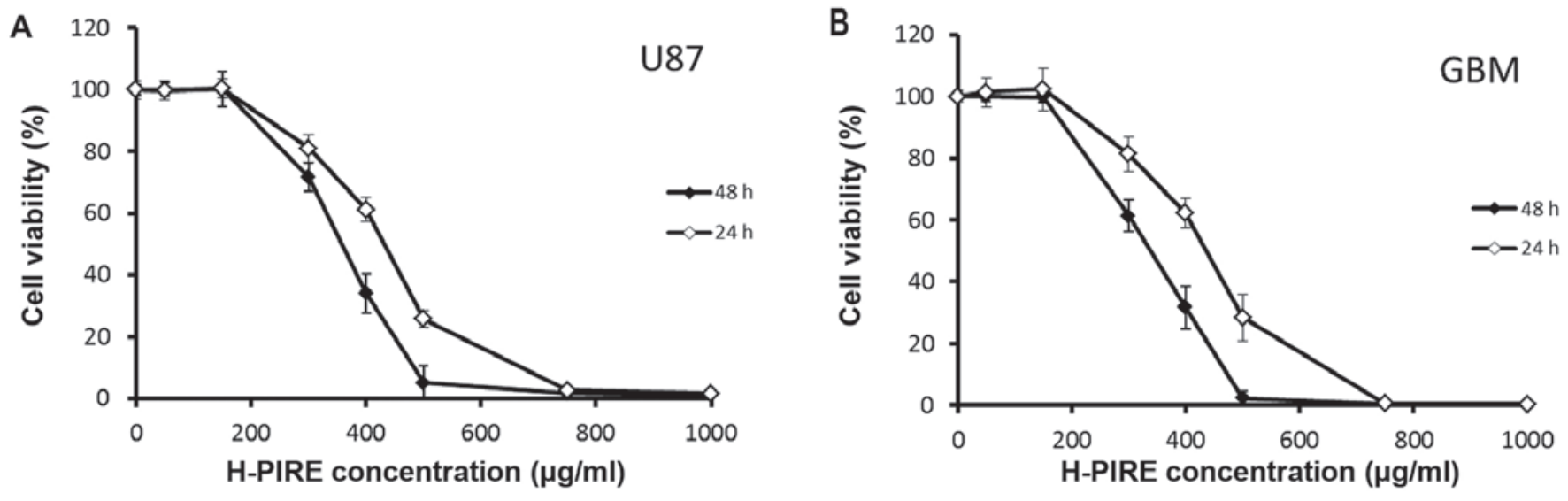

Figure 1. Dose-dependent effect of H-PIRE treatment (0-1,000 $\mu \mathrm{g} / \mathrm{ml})$ on viability of (A) U87 cells and (B) GBM cells. Cell viability was determined by WST-1 assay at 24 and 48 h. H-PIRE, hexane fraction of Pluchea indica root extract; GBM, glioblastoma multiforme.
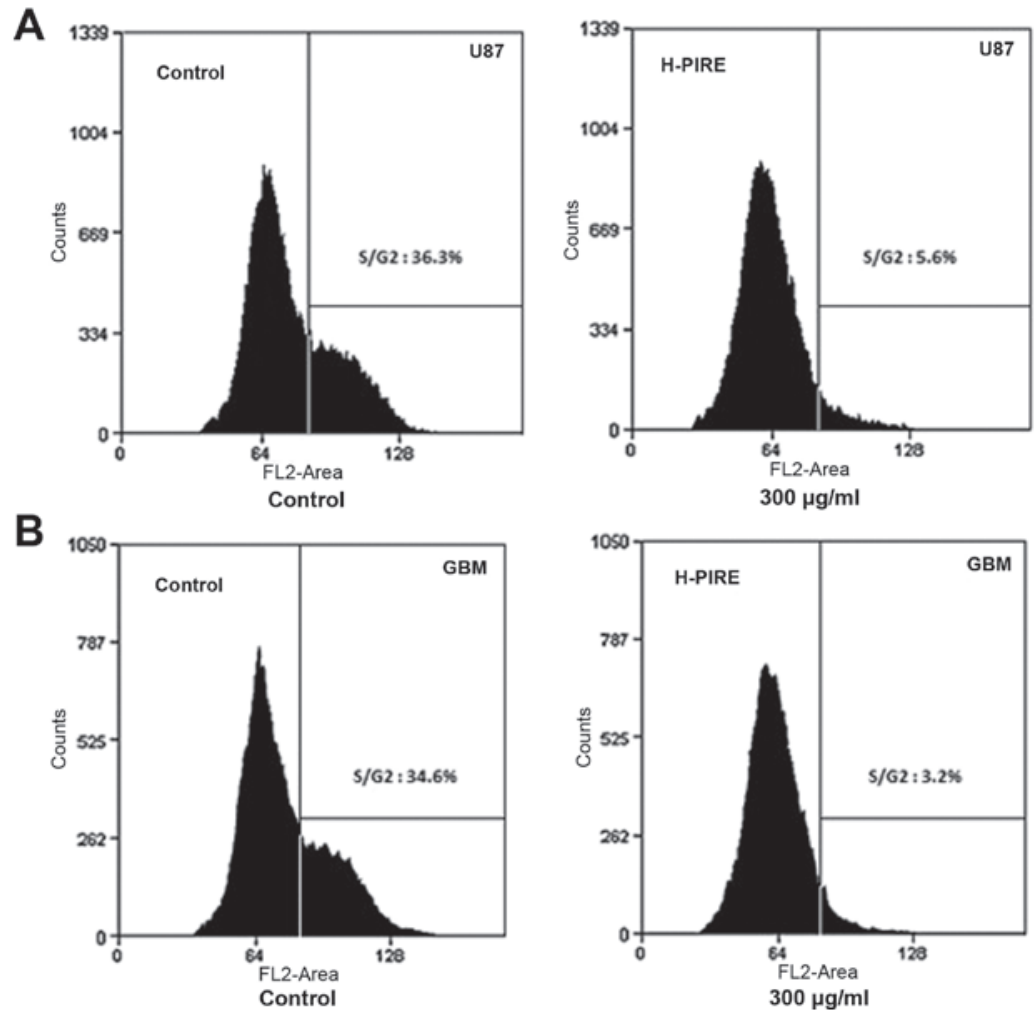

Figure 2. Results of cell cycle analysis of (A) U87 cells and (B) GBM cells after $24 \mathrm{~h}$ treatment with $0.1 \%$ DMSO (control) or $300 \mu \mathrm{g} / \mathrm{ml} \mathrm{H-PIRE.} \mathrm{Cell} \mathrm{cycle}$ analysis was performed by flow cytometry in cells stained with PI. GBM, glioblastoma multiforme; DMSO, dimethyl sulfoxide; H-PIRE, hexane fraction of Pluchea indica root extract; PI, propidium iodide.

\section{Results}

Phytochemical screening. Table I shows that the preliminary phytochemical analysis of H-PIRE revealed a high content of phenols, flavonoids and proanthocyanidins, which are biologically active phytochemical compounds found in many medicinal herbal extracts. Secondary metabolites such as polyphenols and flavonoids interact with proteins and are useful for inhibiting multidrug resistance (25), suppressing tumor angiogenesis and preventing inflammation (26). Thus, the phytochemical composition of H-PIRE was consistent with the reported medicinal properties of $P$. indica.
Suppression of GBM cell proliferation by H-PIRE. The cytotoxic effects of H-PIRE on GBM cells were examined by assays of WST-1 cell proliferation. Two GBM cell lines were treated with varying concentrations of H-PIRE (range, $0-1,000 \mu \mathrm{g} / \mathrm{ml}$ ) at 24 and $48 \mathrm{~h}$. Fig. 1 shows the experimental results. In both cell lines, H-PIRE reduced cell viability in a dose-dependent manner. At 24 and $48 \mathrm{~h}$, the $\mathrm{IC}_{50}$ values (mean $\pm \mathrm{SD}, \mu \mathrm{g} / \mathrm{ml}$ ) for H-PIRE were $422.6 \pm 38.3$ and $353.3 \pm 18.7$ in U87 cells and $416.4 \pm 35.5$ and $334.1 \pm 29.6$ in GBM cells, respectively. That is, the $\mathrm{IC}_{50}$ values indicated that H-PIRE suppressed proliferation in both human GBM cell lines. 
$\mathrm{Oh}$
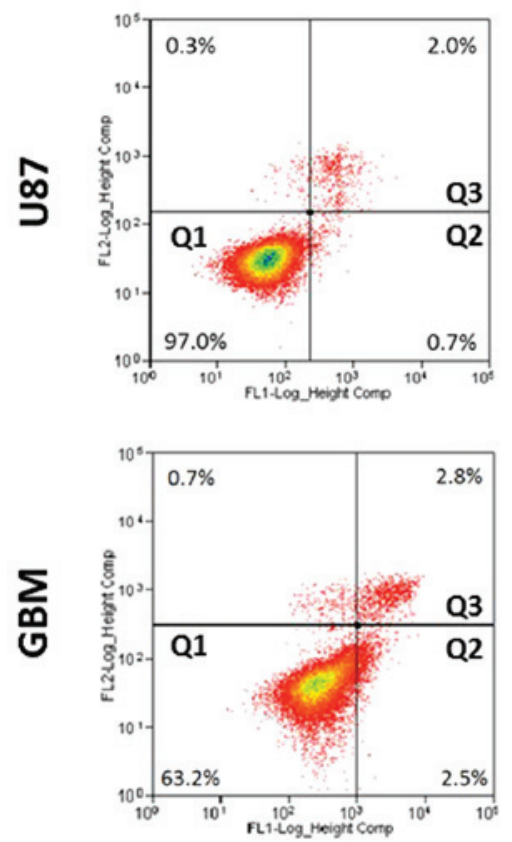

$24 \mathrm{~h}$
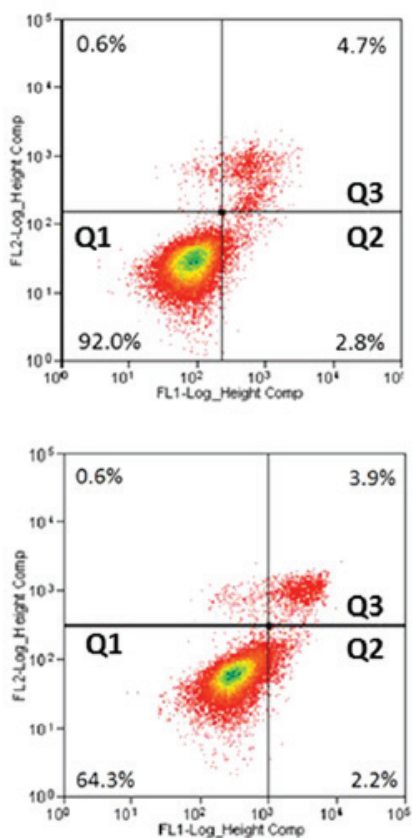

$48 \mathrm{~h}$
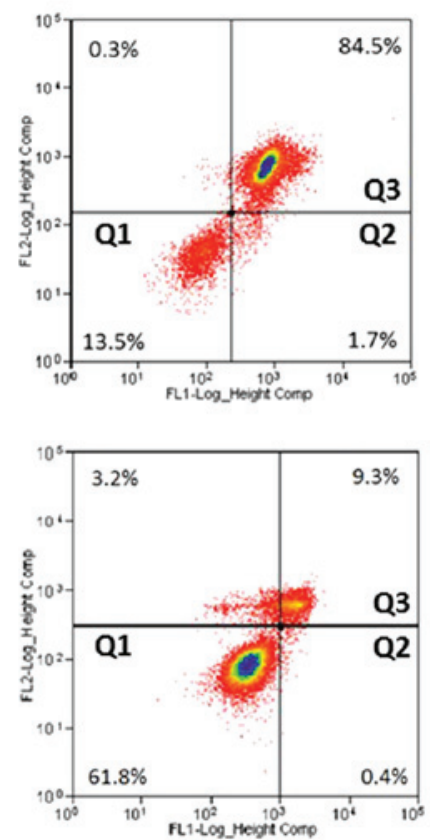

Figure 3. Results of flow cytometric analysis of apoptosis in U87 and GBM cells treated with $300 \mu \mathrm{g} / \mathrm{ml} \mathrm{H-PIRE}$ for 0,24 and $48 \mathrm{~h}$ then stained with FITC-Annexin V and PI. Q1, the lower-left quadrant shows living cells; Q2, the lower-right quadrant shows early apoptotic cells; and Q3, the upper-right quadrant shows necrotic or late-apoptotic cells. GBM, glioblastoma multiforme H-PIRE, hexane fraction of Pluchea indica root extract; FITC, fluorescein isothiocyanate; PI, propidium iodide.
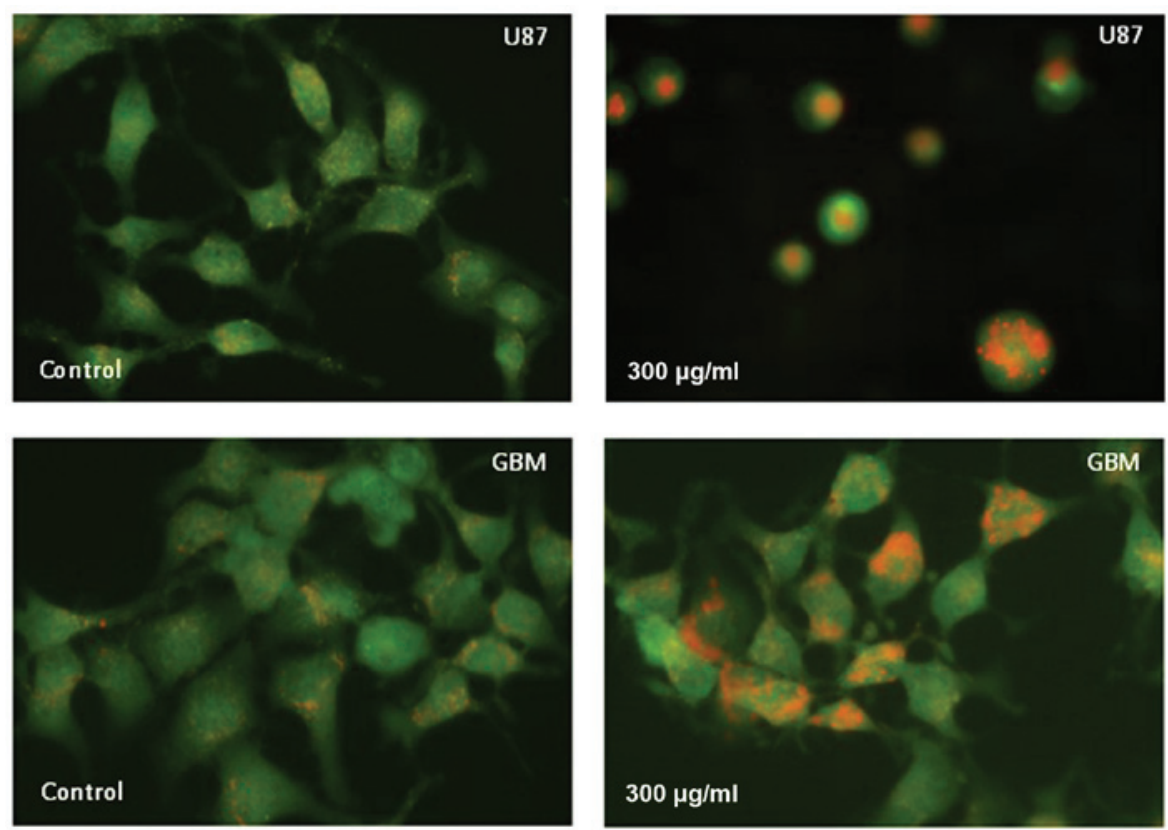

Figure 4. Fluorescence microscopic images of U87 and GBM cells stained with AO. Cells were treated with 0.1\% DMSO (control) or $300 \mu \mathrm{g} / \mathrm{ml}$ of H-PIRE for $24 \mathrm{~h}$. Merging green and red channels are visible. AO, acridine orange; GBM, glioblastoma multiforme; H-PIRE, hexane fraction of Pluchea indica root extract; DMSO, dimethyl sulfoxide.

Suppression of cell cycle progression by H-PIRE. The effect of H-PIRE on the cell cycle was investigated by flow cytometry. The U87 and GBM cells were incubated with $300 \mu \mathrm{g} / \mathrm{ml}$ H-PIRE for $24 \mathrm{~h}$. The incubated cells were then collected, fixed and stained with PI for flow cytometric analysis of DNA content. Fig. 2 shows that the H-PIRE treatment significantly decreased the cell populations in the $\mathrm{S}$ and $\mathrm{G} 2 / \mathrm{M}$ phases.
However, the sub-G1 population showed no increase, which indicated that the treatment did not induce apoptosis. Thus, H-PIRE suppressed progression of the human GBM cell cycle through the G0/G1 phase.

Induction of apoptosis by H-PIRE. Apoptotic effects of H-PIRE were investigated by flow cytometry of unfixed cells 
A

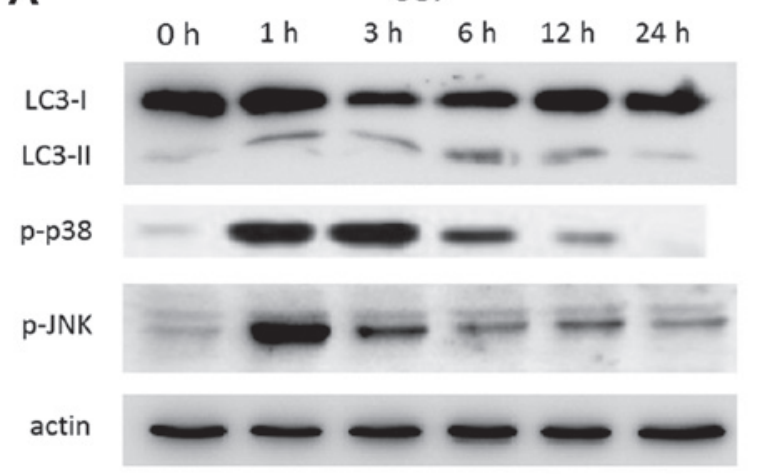

B
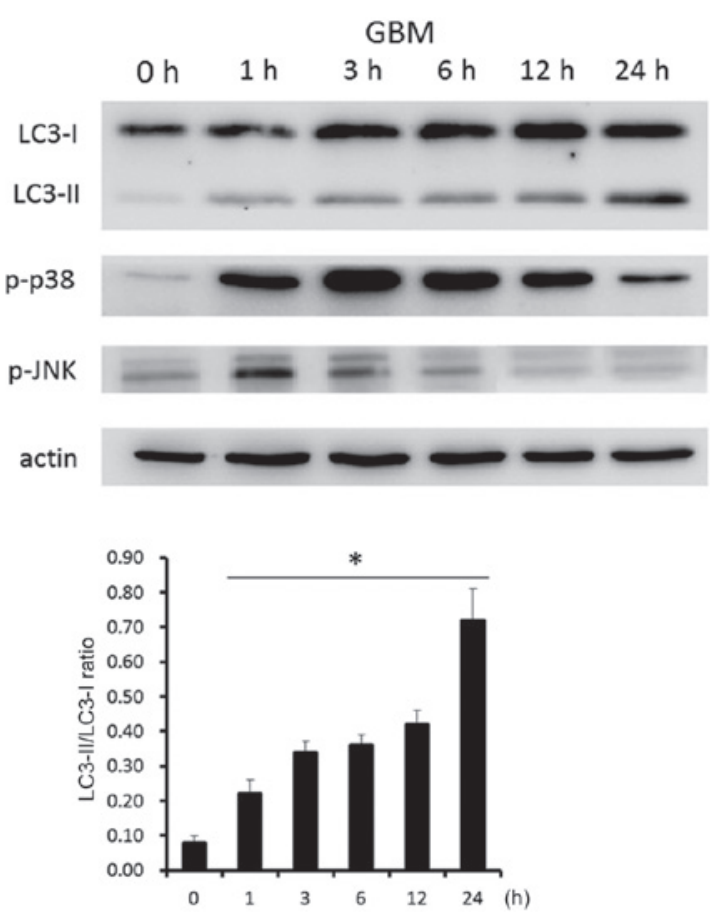

Figure 5. Expression of LC3, p-p38 and p-JNK proteins in GBM cells. (A) Results of western blot analysis of LC3, p-p38 and p-JNK proteins in U87 and GBM cells after varying durations of treatment with $300 \mu \mathrm{g} / \mathrm{ml} \mathrm{H-PIRE.} \mathrm{(B)} \mathrm{The} \mathrm{LC3-II/LC3-I} \mathrm{ratio} \mathrm{changed} \mathrm{in} \mathrm{a} \mathrm{time-dependent} \mathrm{manner.} \mathrm{Results} \mathrm{are} \mathrm{presented}$ as means $\pm \mathrm{SD}$ in three experiments. ${ }^{*} \mathrm{P}<0.05$ in comparison with baseline. SD, standard deviation; H-PIRE, hexane fraction of Pluchea indica root extract.

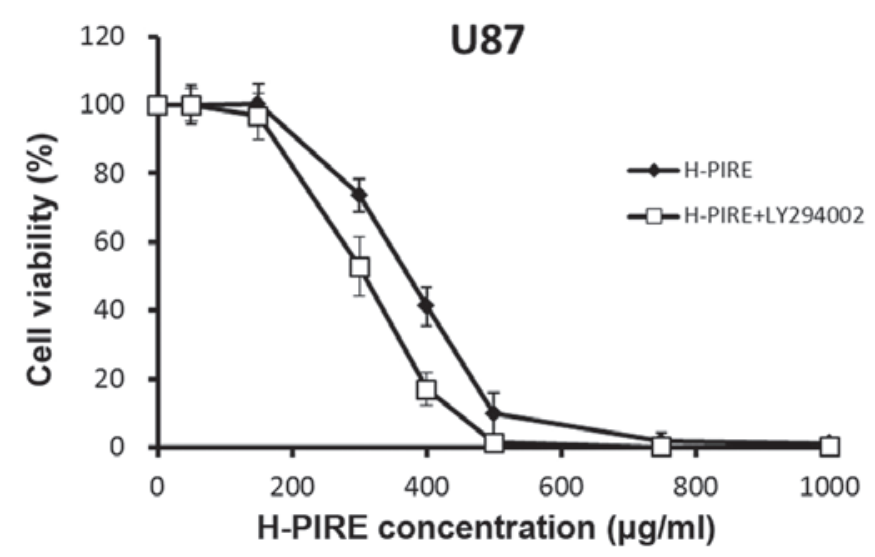

Figure 6. Combined treatment with H-PIRE and LY294002 had additive effects on human GBM cell survival. The U87 cells were treated with $0-1,000 \mu \mathrm{g} / \mathrm{ml} \mathrm{H}$-PIRE, with or without $10 \mu \mathrm{M}$ LY294002, for $48 \mathrm{~h}$. Cell viability was determined by WST-1 assay. H-PIRE, hexane fraction of Pluchea indica root extract.

stained with Annexin V and PI. Fig. 3 shows that, at 24 and $48 \mathrm{~h}$ after treatment with $300 \mu \mathrm{g} / \mathrm{ml} \mathrm{H-PIRE}$, the U87 and GBM cells showed significantly increased percentages of dead cells in quadrant 3 but no increase in early apoptosis in quadrant 2. These experimental results suggest that cell death induced by H-PIRE in glioblastoma cells is probably not associated with apoptosis.

Detection of AVOs. Formation of AVOs, which is a morphological characteristic of cells undergoing autophagy, can be detected by fluorescence microscopy of living cells stained with AO, which emits red fluorescence at low $\mathrm{pH}$. The staining results in Fig. 4 show that AVO expression was increased in U87 and GBM cells at $24 \mathrm{~h}$ after treatment with $300 \mu \mathrm{g} / \mathrm{ml}$ H-PIRE. These results clearly indicate that H-PIRE induces autophagy in human glioblastoma cells.

Expression of autophagy-related proteins. The mechanism of cell death induced by H-PIRE was investigated by examining the expression of autophagy-related proteins in U87 and GBM cells. The cells were treated with $300 \mu \mathrm{g} / \mathrm{ml}$ of H-PIRE for 0 to $24 \mathrm{~h}$. Western blot analysis was then used to examine the expression of microtubule-associated protein light chain 3 (LC3)-I, LC3-II, phosphorylated-p38 and phosphorylated-JNK. Fig. 5A shows that, at $1 \mathrm{~h}$ after the H-PIRE treatment, LC3-II was significantly upregulated relative to LC3-I, which significantly increased autophagosome formation (27). In both cell lines, expression of phosphorylated-p38 protein was significantly increased at $1 \mathrm{~h}$ after H-PIRE treatment and peaked at $3 \mathrm{~h}$ after treatment. Phosphorylated-p38 protein expression remained at the peak level for $>12 \mathrm{~h}$ in U87 cells and for $24 \mathrm{~h}$ in GBM cells before dropping back to the base level. Expression of phosphorylated-JNK protein was substantially increased at $1 \mathrm{~h}$ after H-PIRE treatment and then gradually decreased to the base level in the two cell lines. The results indicated that, in both cell lines, the stress induced by H-PIRE activated the p38 and JNK signaling pathways, which are known to play key roles in the induction of autophagy (27).

Fig. 5B shows that the LC3-II/LC3-I ratio increased in a time-dependent manner in both cell lines. The ratio peaked at 0.30 at $1 \mathrm{~h}$ and started to decline after $12 \mathrm{~h}$ in U87 cells. By contrast, the ratio increased steadily and peaked at 0.73 at $24 \mathrm{~h}$ in GBM cells. In addition, H-PIRE treatment resulted in different FITC-AV and PI staining pattern at 48 h (Fig. 3) 
and cell morphology at $24 \mathrm{~h}$ (Fig. 4) in U87 and GBM cells. These data may reflect the intrinsic difference in the manner the two types of cells responded to autophagic stress. The overall results indicate that H-PIRE activates p38 and JNK and induces autophagy in human GBM cells.

Additive cytotoxic effects of combined treatment with H-PIRE with PI3K inhibitor. Rapamycin and LY294002 (a pan-PI3K inhibitor) reportedly exert synergistic effects on the induction of autophagy and reduction of cell survival in malignant glioma cell lines, including U87 (28). Specifically, rapamycin induces autophagy by deactivating mTOR (29). To determine whether inhibition of the PI3K pathway and H-PIRE treatment synergistically affect cell viability, U87 cells were treated with H-PIRE $(0-1,000 \mu \mathrm{g} / \mathrm{ml})$ with or without $10 \mu \mathrm{M}$ LY274002. Fig. 6 shows the cell viability assay results, which indicated that the addition of LY294002 enhanced the reduction of cell viability induced by H-PIRE treatment. The addition of LY294002 reduced IC $_{50}$ of H-PIRE from $353.3 \pm 18.7$ to $298.6 \pm 20.3 \mu \mathrm{g} / \mathrm{ml}$. These results indicate that the combined treatment of H-PIRE and LY294002 have additive effects on the reduction of cell survival in human GBM cells.

\section{Discussion}

Previous findings have demonstrated the anticancer properties of crude aqueous fraction and ethanol fraction of the $P$. indica root extract (20). The present study further investigated the suppressive effects of H-PIRE on GBM cells. The hydrophobic nature of H-PIRE enables it to penetrate the blood-brain barrier and effectively target GBM cells in the brain.

Our experimental results indicate that H-PIRE has a potent suppressive effect on human GBM cell growth, apparently by inducing cell cycle arrest in the G0/G1 phase but without inducing apoptosis (the sub-G1 fraction). However, due to the complex nature of H-PIRE, we cannot exclude that apoptosis may be induced by H-PIRE at much higher concentrations. Another possible mechanism of the suppressive effects of H-PIRE is the induction of autophagy through the increased formation of AVOs, increased expression of LC3-II, and increased phosphorylation of JNK and p38 proteins.

The activation of p38 and JNK is usually associated with antiproliferative activity (30) and induction of autophagy $(31,32)$. Recent studies suggest that p38 and JNK have important roles in the crosstalk between apoptosis and autophagy under cellular stress conditions (33). Although autophagy may be associated with cell survival or death (34), significantly higher than normal autophagy is usually associated with cell death (35). Although inducing autophagy is considered an effective way to induce GBM cell death $(36,37)$, our experiments showed that GBM cells are insensitive to most apoptotic stimuli.

The PI3K, the protein kinase B (Akt), and the mammalian target of rapamycin (mTOR) form a cell survival pathway important for cell growth and proliferation. This pathway is also critical for tumorigenesis (38) and is now recognized as an important target in cancer treatment (39). Our experiments showed that pre-treating U87 cells with LY294002 inhibited PI3K activity, which then increased their sensitivity to H-PIRE treatment. Thus, since H-PIRE treatment substantially reduces GBM cell survival through an autophagy-related pathway, combined treatments with H-PIRE and other growth inhibitors may have synergistic effects in conventional cancer treatment.

In conclusion, findings of this study show that H-PIRE suppresses proliferation and reduces viability in GBM cells. As it activates the p38 and JNK pathways, H-PIRE can also be used to induce autophagy in GBM cells. However, further studies are needed to elucidate the molecular pathway of anticancer activity induced by H-PIRE.

\section{Acknowledgements}

This study was supported by grants from the "Aim for the Top University Plan' of the National Sun Yat-sen University and from the NSYSU-KMU Joint Research Project (no. NSYSUKMU 105-P012) and MOST 104-2320-B-037-030-MY3 from the Ministry of Science and Technology (Taiwan, R.O.C.). We would like to thank Dr L-J Liao (National Kaohsiung Normal University, Kaohsiung, Taiwan, R.O.C.) for providing and authenticating the $P$. indica plants used in experiments in the present study.

\section{References}

1. Bleeker FE, Molenaar RJ and Leenstra S: Recent advances in the molecular understanding of glioblastoma. J Neurooncol 108: $11-27,2012$

2. Bleeker FE, Lamba S, Zanon C, Molenaar RJ, Hulsebos TJM, Troost D, van Tilborg AA, Vandertop WP, Leenstra S, van Noorden CJF, et al: Mutational profiling of kinases in glioblastoma. BMC Cancer 14: 718, 2014.

3. Crawford JR, Santi MR, Thorarinsdottir HK, Cornelison R, Rushing EJ, Zhang H, Yao K, Jacobson S and Macdonald TJ: Detection of human herpesvirus- 6 variants in pediatric brain tumors: Association of viral antigen in low grade gliomas. J Clin Virol 46: 37-42, 2009.

4. Baglietto L, Giles GG, English DR, Karahalios A, Hopper JL and Severi G: Alcohol consumption and risk of glioblastoma; evidence from the Melbourne Collaborative Cohort Study. Int J Cancer 128: 1929-1934, 2011

5. Braganza MZ, Kitahara CM, Berrington de González A, Inskip $\mathrm{PD}$, Johnson KJ and Rajaraman P: Ionizing radiation and the risk of brain and central nervous system tumors: A systematic review. Neuro-oncol 14: 1316-1324, 2012.

6. Ellis HP, Greenslade M, Powell B, Spiteri I, Sottoriva A and Kurian KM: Current challenges in glioblastoma: Intratumour heterogeneity, residual disease and models to predict disease recurrence. Front Oncol 5: 251, 2015.

7. Johnson DR and O'Neill BP: Glioblastoma survival in the United States before and during the temozolomide era. J Neurooncol 107: 359-364, 2012.

8. Wrensch M, Minn Y, Chew T, Bondy M and Berger MS: Epidemiology of primary brain tumors: Current concepts and review of the literature. Neuro Oncol 4: 278-299, 2002.

9. Emsen B, Aslan A, Togar B and Turkez H: In vitro antitumor activities of the lichen compounds olivetoric, physodic and psoromic acid in rat neuron and glioblastoma cells. Pharm Biol 54: 1748-1762, 2016.

10. Mulpur BH, Nabors LB, Thompson RC, Olson JJ, LaRocca RV, Thompson $\mathrm{Z}$ and Egan KM: Complementary therapy and survival in glioblastoma. Neurooncol Pract 2: 122-126, 2015.

11. Sen T, Dhara AK, Bhattacharjee S, Pal S and Nag Chaudhuri AK: Antioxidant activity of the methanol fraction of Pluchea indica root extract. Phytother Res 16: 331-335, 2002.

12. Ab Rahman MR, Abdul Razak F, Mohd Bakri M: Evaluation of wound closure activity of Nigella sativa, Melastoma malabathricum, Pluchea indica and Piper sarmentosum extracts on scratched monolayer of human gingival fibroblasts. Evid Based Complement Alternat Med 2014: 190342, 2014

13. Arsiningtyas IS, Gunawan-Puteri MD, Kato E and Kawabata J: Identification of $\alpha$-glucosidase inhibitors from the leaves of Pluchea indica (L.) Less., a traditional Indonesian herb: Promotion of natural product use. Nat Prod Res 28: 1350-1353, 2014. 
14. Gomes A, Saha A, Chatterjee I and Chakravarty AK: Viper and cobra venom neutralization by $\beta$-sitosterol and stigmasterol isolated from the root extract of Pluchea indica Less. (Asteraceae). Phytomedicine 14: 637-643, 2007.

15. Biswas R, Dutta PK, Achari B, Bandyopadhyay D, Mishra M Pramanik KC and Chatterjee TK: Isolation of pure compound $\mathrm{R} / \mathrm{J} / 3$ from Pluchea indica (L.) Less. and its anti-amoebic activities against Entamoeba histolytica. Phytomedicine 14 534-537, 2007.

16. Sen T, Ghosh TK and Chaudhuri AK: Studies on the mechanism of anti-inflammatory and anti-ulcer activity of Pluchea indica-probable involvement of 5-lipooxygenase pathway. Life Sci 52: 737-743, 1993

17. Mohamad S, Zin NM, Wahab HA, Ibrahim P, Sulaiman SF, Zahariluddin ASM and Noor SSM: Antituberculosis potential of some ethnobotanically selected Malaysian plants. J Ethnopharmacol 133: 1021-1026, 2011.

18. Locher CP, Witvrouw M, De Béthune MP, Burch MT, Mower HF, Davis H, Lasure A, Pauwels R, De Clercq E and Vlietinck AJ: Antiviral activity of Hawaiian medicinal plants against human immunodeficiency Virus Type-1 (HIV-1). Phytomedicine 2: 259-264, 1996

19. Ohtsuki T, Yokosawa E, Koyano T, Preeprame S, Kowithayakorn T, Sakai S, Toida T and Ishibashi M: Quinic acid esters from Pluchea indica with collagenase, MMP-2 and -9 inhibitory activities. Phytother Res 22: 264-266, 2008.

20. Cho JJ, Cho CL, Kao CL, Chen CM, Tseng CN, Lee YZ, Liao LJ and Hong YR: Crude aqueous extracts of Pluchea indica (L.) Less. inhibit proliferation and migration of cancer cells through induction of p53-dependent cell death. BMC Complement Altern Med 12: 265, 2012.

21. Kao CL, Cho J, Lee YZ, Cheng YB, Chien CY, Hwang CF, Hong YR, Tseng CN and Cho CL: Ethanolic extracts of Pluchea indica induce apoptosis and antiproliferation effects in human nasopharyngeal carcinoma cells. Molecules 20: 11508-11523, 2015.

22. Harborne JB: Phytochemical methods: a guide to modern techniques of plant analysis. 3rd edition. Chapman and Hall, London, UK, 1998.

23. Butler LG, Price ML and Brotherton JE: Vanillin assay for proanthocyanidins (condensed tannins): Modification of the solvent for estimation of the degree of polymerization. J Agric Food Chem 30: 1087-1089, 1982.

24. Pavon LF, Marti LC, Sibov TT, Malheiros SM, Brandt RA, Cavalheiro $S$ and Gamarra LF: In vitro analysis of neurospheres derived from gioblastoma primary culture: A novel methodology paradigm. Front Neurol 4: 214, 2014.

25. Wink M, Ashour ML and El-Readi MZ: Secondary metabolites from plants inhibiting $\mathrm{ABC}$ transporters and reversing resistance of cancer cells and microbes to cytotoxic and antimicrobial agents. Front Microbiol 3: 130, 2012.
26. Tabrez S, Priyadarshini M, Urooj M, Shakil S, Ashraf GM, Khan MS, Kamal MA, Alam Q, Jabir NR, Abuzenadah AM, et al: Cancer chemoprevention by polyphenols and their potential application as nanomedicine. J Environ Sci Health C Environ Carcinog Ecotoxicol Rev 31: 67-98, 2013.

27. Hansen TE and Johansen T: Following autophagy step by step. BMC Biol 9: 39, 2011.

28. Takeuchi H, Kondo Y, Fujiwara K, Kanzawa T, Aoki H, Mills GB and Kondo S: Synergistic augmentation of rapamycin-induced autophagy in malignant glioma cells by phosphatidylinositol 3-kinase/protein kinase B inhibitors. Cancer Res 65: 3336-3346, 2005.

29. Berger Z, Ravikumar B, Menzies FM, Oroz LG, Underwood BR Pangalos MN, Schmitt I, Wullner U, Evert BO, O'Kane CJ, et al: Rapamycin alleviates toxicity of different aggregate-prone proteins. Hum Mol Genet 15: 433-442, 2006.

30. Cuadrado A and Nebreda AR: Mechanisms and functions of p38 MAPK signalling. Biochem J 429: 403-417, 2010.

31. Sun T, Li D, Wang L, Xia L, Ma J, Guan Z, Feng G and Zhu X: c-Jun NH2-terminal kinase activation is essential for up-regulation of LC3 during ceramide-induced autophagy in human nasopharyngeal carcinoma cells. J Transl Med 9: 161, 2011.

32. Zhou C, Zhou J, Sheng F, Zhu H, Deng X, Xia B and Lin J: The heme oxygenase-1 inhibitor ZnPPIX induces non-canonical, Beclin 1-independent, autophagy through p38 MAPK pathway. Acta Biochim Biophys Sin (Shanghai) 44: 815-822, 2012.

33. Sui X, Kong N, Ye L, Han W, Zhou J, Zhang Q, He C and Pan H: p38 and JNK MAPK pathways control the balance of apoptosis and autophagy in response to chemotherapeutic agents. Cancer Lett 344: 174-179, 2014

34. Tanida I: Autophagosome formation and molecular mechanism of autophagy. Antioxid Redox Signal 14: 2201-2214, 2011.

35. Shimizu S, Yoshida T, Tsujioka M and Arakawa S: Autophagic cell death and cancer. Int J Mol Sci 15: 3145-3153, 2014.

36. Koukourakis MI, Mitrakas AG and Giatromanolaki A: Therapeutic interactions of autophagy with radiation and temozolomide in glioblastoma: Evidence and issues to resolve. Br J Cancer 114: 485-496, 2016.

37. Yan Y, Xu Z, Dai S, Qian L, Sun L and Gong Z: Targeting autophagy to sensitive glioma to temozolomide treatment. J Exp Clin Cancer Res 35: 23, 2016.

38. Nicholson KM and Anderson NG: The protein kinase B/Akt signalling pathway in human malignancy. Cell Signal 14: 381-395, 2002.

39. Morgensztern D and McLeod HL: PI3K/Akt/mTOR pathway as a target for cancer therapy. Anticancer Drugs 16: 797-803, 2005. 